\title{
Sport mega-events and 'terrorism': A critical analysis
}

\author{
Richard Giulianotti and Francisco Klauser \\ This is a copy of the Author's Original Text of an article whose final and definitive from, the \\ Version of Record, has been published in International Review for the Sociology of Sport [copyright \\ Sage Publications], DOI: 10.1177/1012690211433454
}

To Cite: Giulianotti, R. and Klauser, F., (2012) Sport Mega-Events and 'Terrosim': A Critical Analysis, International Review for the Sociology of Sport, 47:3, 307-323.

Published Version Available At: http://irs.sagepub.com/content/47/3/307.abstract

\begin{abstract}
The article explores critically the interplay between sport and terrorism, with particular reference to sport megaevents. Our discussion is divided into two main sections. First, we set out the main principles of a critical social theoretical approach, which enables satisfactory analysis of the 'sport/ terrorism' couplet. We discuss the contribution of three types of critical perspective that are tied to different disciplines, namely sociology, human geography, and political science/ international relations. Second, we turn to consider some of the main historical and contemporary incidents and issues with regard to terrorism at sport mega-events. On this basis, we show how and why social scientific analysis needs to move beyond common-sense understandings of the sport/ terrorism couplet, to investigate critically the epistemologies and discursive constructions of terror, the logics, processes and relationships underpinning specific counter-terrorism strategies, and the wider socio-spatial implications thereof.
\end{abstract}

Keywords: cities, critical social theory, sport mega-events, terrorism

Security and counter-terrorism strategies are now established as key themes in the staging of sport mega-events. Security budgets have multiplied in the post-9/11 context, from around US\$66.2 million for the 1992 Barcelona Olympics to US\$6.5 billion for the 2008 Beijing Games (The Times, 3 August 2008). The everyday experience of sport mega-events is increasingly marked by security-related features, such as the enforced closure of public thoroughfares, the searching of individuals in and around stadiums, the constant surveillance of spectators and local residents by CCTV cameras, the routine drone of overhead helicopters or unmanned aircraft that are filming the public below, and the familiar presence of fully equipped police officers and military personnel at street corners or sites of particular public interest.

In this article, we explore critically the interplay between sport and terrorism (or, as we state regularly here, the sport/terrorism couplet) with particular reference to sport mega-events. Our broad aim is to set out the main principles of a critical social theory which enables satisfactory 
analysis of the sport/terrorism couplet. Despite the substantive focus of this article on sport/terrorism, we argue that the broad epistemological, methodological and normative aspects of this critical social theory may be applied in many other fields of social scientific inquiry, such as in regard to sport, social policy, urban development, or globalization, to list but a few possibilities. After setting out this critical social theory, we turn to consider in turn some of the main historical and contemporary events and issues in regard to the sport/terrorism couplet.

\section{A critical social scientific theory of sport and terrorism}

'Terror', 'terrorism' and 'terrorist' are terms that carry enormous political loading and rarely generate agreement on their definitions. Different communities seek to define the violent actions of their enemies and opponents as 'terrorist', while absolving their own practices of such negative association (Keohane, 2002: 77). In arriving at a broad social scientific definition, we turn here to Tilly (2004: 5), who defined terror as a 'political strategy' which involves the 'asymmetrical deployment of threats and violence against enemies using means that fall outside the forms of political struggle routinely operating within some current regime'. The term 'terror' first emerged in Western political discourse during the revolutionary French government's 'Reign of Terror' (1793-1795), which was directed against perceived internal enemies (Tilly, 2004: 8-9). Thus, 'terror' constitutes a strategy employed by diverse social individuals, groups and institutions, ranging from state to non-state actors, from outlaws to government officials, with respect to the prosecution of specific political struggles.

In this discussion, we advocate a critical social scientific standpoint for examining the 'sport/terrorism' couplet. Our standpoint integrates three types of critical perspective that are tied to different disciplines, namely sociology, human geography, and political science/international relations. In the following, we set out briefly each of these three positions, and identify the common features to be included within our analytical framework.

First, in sociology, the critical standpoint has tended to be associated mostly with the critical theory of the Frankfurt School, which particularly in the mid-20th century had offered concerted neoMarxist critiques of industrial rationalization, modern capitalism, and the corruption of the cultural sphere by the growth of the commercial Culture Industry (Adorno and Horkheimer, 1979; Marcuse, 1986). Here, we move beyond this specific theoretical lineage, to understand critical sociology with reference to a broader set of methodological and theoretical commitments, in terms of exposing falsities, correcting misunderstandings, and exploring alternative possibilities to existing arrangements for social life (see Willis, 1996). Thus, for Calhoun (1993: 
63), critical theory constitutes a form of theorizing which 'undertakes simultaneously critique of received categories, critique of theoretical practice, and critical substantive analysis of social life in terms of the possible, not just the actual'. For Calhoun (1995: 36), drawing on Charles Taylor, critical theorists 'do not work in a world of right answers', but instead confront different theories, with their partial strengths and weaknesses, in order to achieve 'epistemic gains'; that is, 'a movement from a problematic position to a more adequate one'. This expansive definition ensures that diverse theorists such as Bourdieu, Foucault, and Haraway join the Frankfurt School within the 'critical theory' category.

Our second disciplinary influence - buman geography - enables us to explore the concept of the 'critical' from at least three interrelated angles. First, the 'critical' is associated with an analytical focus on the constitutive role of space and scale in contemporary power relations and political struggles. In this, emphasis is commonly placed on 'the urban', as the locus, tool and means par excellence of different socio-political forms of power and resistance. In addressing these issues, a wide range of critical theoretical approaches are mobilized, including post-colonialism, feminism, and post-structuralism (Desbiens and Smith, 1999; Katz, 1998; Lees, 1999), thus extending, and elaborating upon, the traditionally more orthodox Marxist tradition in Radical Geography. Second, 'critical' takes a methodological meaning, implying a self-reflective approach regarding the purpose and practice of academic/geographic research and knowledge (Lees, 1999). Relevant debates focus on how, where, by whom, and to what effect and benefit, academic knowledge is produced and 'consumed'. Third, and following from the previous points, critical human geography stands for a shared concern for issues of social and spatial justice (Harvey, 1973), combined with an (albeit contested) commitment to socio-political change.

This article draws mainly upon the first, analytical contribution of critical human geography. In its focus on the reciprocal implications between power, space and scale, we consider that critical geography offers useful additions for understanding how terrorism threats, and counterterrorism policies, permeate and produce urban space at sport mega-events. A critical social scientific standpoint for examining the 'sport/terrorism' couplet, such is our key argument, also needs to explore the cross-scalar processes and exchanges through which specific counterterrorism dispositifs (Foucault, 2009) are developed, and to address critically the wider, and often long-term, socio-spatial implications thereof. Relevant questions to address include: how do particular (public-private; local-national-international) forms of expertise and bodies of knowledge relating to sport and terrorism become authorized to act in specific places and at 
specific moments? And what are the wider socio-spatial, economic, political, etc., implications of mega-event securitization both during and after the event?

Our third disciplinary influence in regard to critical thinking is international relations, and in particular the emerging standpoint of critical terrorism studies (CTS). 'Terrorism studies' has long been a well resourced and established sub-discipline within international relations, but it has been seriously rethought and problematized by the emergence of CTS in recent years. CTS analysts are deeply critical of the ways in which conventional terrorism studies has been overly reliant on an uncritical acceptance of official sources in the reporting and analysis of 'terrorist' incidents and groups, to the extent that this academic sub-discipline has traditionally synchronized rather too well with the standpoints and interests of incumbent Western governments (Raphael, 2009: 58). In contradistinction, the core commitments of CTS include:

1) An appreciation of the politically constructed nature of terrorism knowledge;

2) An awareness of the inherent ontological instability of the 'terrorism' category;

3) A commitment to critical reflexivity in regard to how research findings are applied and used;

4) A set of well-defined research ethics; and

5) A commitment to an emancipatory political praxis (Jackson, 2007: 244, cited in Sluka, 2009: 140).

It should be emphasized that CTS is a diverse rather than unified counter-paradigm within terrorism studies, marshalling different ontological, epistemological and methodological standpoints that are associated, for example, with Frankfurt School critical theory, poststructuralism, and relativist anthropology (Jackson et al., 2009). In Frankfurt School mode, some CTS analysts advocate a 'minimal foundationalism' wherein the category of 'terrorist violence' continues to be applied, but this definition may also encompass state violence and 'counterterrorism', as well as some groups that are labelled 'terrorists' by nation-states. The Frankfurt School type of CTS also advocates an emancipatory politics that gives voice to the voiceless (McDonald, 2009; Toros and Gunning, 2009). Other analysts lean more to the post-structuralist side by putting greater focus on critical deconstructions of the dominant discourses or 'myths' surrounding terrorism, to the extent that, for analytical purposes, the term 'terrorist' is considered to be fatally compromised (Said, 1988; Sluka, 2009; Zulaika, 2009; Zulaika and Douglass, 1996). While recognizing the benefits of the post-structuralist approach, our own perspective leans more towards the Frankfurt School tradition for two main reasons: first, this enables us to retain the potential social scientific meaningfulness of the term 'terror', in line with 
Tilly's definition as set out earlier, while also being watchful in regard to the way that this term is deployed as a political label on a case-by-case basis; and second, to enable us to employ a normative standpoint which engages with issues of social justice.

The three approaches that are set out here - sociological, human geographical, and CST - are broadly compatible, in terms of epistemology, methodology, and politics. Here, we itemize their main continuities, and set out the implications for social scientists who are investigating the sport/terrorism couplet:

1) Epistemologies and discursive constructions of terror: Drawing on the three disciplinary approaches, social scientists who are analysing the sport/terrorism couplet may examine the multiple, cross-scalar power relations and dynamics that underpin both knowledge construction and definitions of terror, terrorism and terrorists with regard to sport and sport mega-events.

2) Strategies and structures of anti-terrorism: Social scientists may address the technologies, institutions and organizational structures that are constructed to counteract perceived terrorist threats, and how forms of knowledge transfer occur across these assemblages. Of particular interest here in current times is the development of new public-private partnerships and military involvement in constructing these anti-terrorist techniques and relationships.

3) Methods and scale: Social scientists may explore how any sport/terrorism issue or episode extends beyond specific spatial and substantive fields, for example in regard to going beyond national borders and boundaries, and also penetrating into other analytical domains or research fields, such as in the study of urban development policies.

4) Social and spatial justice: Social scientists may examine how any sport/terrorism issue or episode is built out of asymmetrical power relations, and how future strategies may help to facilitate new, progressive and emancipated social arrangements.

5) Socio-spatial implications and security legacies: Social scientists may investigate how security and counter-terrorism policies permeate the production and management of everyday urban spaces both during and after the events. Emphasis should be placed on power inequalities and forms of social exclusion, notably along the lines of class, caste, ethnicity, religion, gender and urban location.

These are important principles that underpin the critical social scientific investigation of the sport/terrorism couplet. However, it is also worth emphasizing that research into specific 
incidents may prioritize some of these principles according to the given context. Thus, for example, 'strategies and structures of anti-terrorism' may be less significant for research into incidents during the early 1970s. The third point which is listed above - relating to methods and scale - is most likely to have strongest utility to researchers investigating the widest variety of case studies or incidents. Moreover, perhaps the most important transformations in recent years have occurred in regard to this third point, on methods and scale; that is, we have witnessed a weakening in the boundary markings that used to define two modern container units, namely the nation-state and the social scientific discipline. There are two sides to this development.

First, particularly in the 9/11 context, a 'de- and re-territorialization' of terror has occurred, as issues and episodes of terrorism have acquired transnational rather than national dimensions (Beck, 2006). Indeed sport mega-events provide exemplary illustrations of both the globalization of social risks and security threats - related not only to terrorism, but also to hooliganism and organized crime - and of the globalization of security partnerships, norms and agreements. The very assessments of terrorist threats depend on a wide range of local, national and transnational factors and issues. For example, as the security coordinator of Geneva Football stadium has put it, in a personal interview before the European Football Championships 2008 in Switzerland and Austria:

Of course, any major geo-strategic and political issue in June will alter the parameters of our [security] problem. For example, developments in Turkey could be difficult for us. One month ago the PKK started bombing some regions. In terms of terrorism, this means we may pass from green to orange or even to red alert. For us, this is a real issue. (Security coordinator Geneva Football stadium, personal interview, 14 February 2008; translation from French)

The global character of sport mega-events finds expression not only in the assessment of the probability of terrorism, but also in the visibility, and hence symbolic impact, of terrorist strikes.

Given that the European Football Championships are broadcast in the entire world, even the smallest incident, broadcast on TV, will take enormous proportions. (Security coordinator Geneva Football stadium, personal interview, 14 February 2008; translation from French)

Thus, for many analysts, this necessitates a move away from 'methodological nationalism', wherein research is undertaken with a specific focus within nation-states. The proposed alternatives include 'methodological cosmopolitanism' or 'methodological globalism', which seem to discard any national focus in favour of a transnational or global methodological frame (Beck, 2007; Holton, 2008). In our view, echoing the critical human geography standpoint, a 
more nuanced approach is provided by 'methodological glocalism' wherein, following Robertson's (1992) conception of glocalization, there is an integration of both the local/national and the global. Thus, researchers who practice methodological glocalism avoid 'the trap of global determinism, while recognizing the robustness of national scales' (Holton, 2008: 199-200). In regard to the sport/terror couplet, methodological glocalism would require researchers to focus on both the local/national and transnational levels, and indeed the interplay of the two.

Second, the public issue and analytical problem of 'terrorism' cannot be compartmentalized or siloed off into a single academic discipline, or a restricted field of substantive inquiry. Rather, major 'spill-overs' occur, in disciplinary and substantive terms, when exploring any issue or episode in the sport/terrorism couplet. Thus, for example, in respect to terrorism and sport mega-events, research would need to explore not just policing and security strategies, but also urban development policies, law, media discourses, sport policy, and general social policy. Such a diverse focus is, of course, facilitated by multi- and trans-disciplinary levels of inquiry.

In the next section, these aspects of a critical social scientific approach are selectively applied, as we turn to explore some of the key historical events and issues in regard to the sport/terrorism couplet. These episodes point in particular to social justice issues and the role of states in shaping meanings and practices in regard to the sport/terror couplet.

\section{Sport and terrorism: Some critical historical events and issues}

The best known and more 'common-sense' understandings of the connections between sport and terrorism would tend to focus on those occasions in which paramilitary forces that are opposed to particular, internationally recognized governments and nation-states, make violent interventions within the field of sport. The most obvious illustration is, of course, the attack on Israeli athletes and coaches by the Palestinian Black September group at the 1972 Olympics in Munich. Eleven Israelis and one West German police officer were killed, along with five of the eight assailants, during a failed rescue mission (Schiller and Young, 2010). More recently, we have witnessed the violent attack by 12 gunmen on Sri Lanka's cricket team in the Pakistani city of Lahore in March 2009, resulting in the death of six police officers and two civilians (Shah and Pallister, 2009).

As we have argued, critical social scientific analysis needs to move beyond common-sense reporting of such incidents. In regard to the Lahore incident, for example, we may examine how international media reports failed to provide sufficient background and context to make the 
attacks meaningful; how subsequent anti-terror strategies in cricket had wider reverberations within and beyond the game; and how, in regard to social justice issues, little analysis was given over in media and elsewhere to the everyday risks that are endured by Pakistani citizens, or to the social roots of the conflicts that led to the attack. The attack was one aspect of the wider security concerns in the Asian sub-continent which had direct commercial and organizational effects on world cricket. Several international teams had refused to tour in Pakistan from 2001 onwards. India had cancelled a tour after the Islamic militant attacks on Mumbai in 2008 which had resulted in 164 deaths. After both attacks, the IPL (Indian Premier League) cricket tournament was transferred from India to South Africa, when the Indian government stated that it could not guarantee security (Manthorp, 2009). In this latter case, the wider structural and social impacts of security responses included direct effects on the tournament per se (leading to a shorter event, played in different conditions); the players (who received less money for playing fewer games); spectators (as games were played before smaller crowds and television audiences, with very few Indian fans able to attend); and national commercial sectors (with the tournament's relocation costing Indian businesses tens of millions of pounds, but boosting the South African economy) (Wilson, 2009). From a critical social scientific perspective, it is of crucial importance also to examine the debates and discourses on the identities of the attackers. For Pakistani police, the main suspects were associates of banned Islamic groups with ties to al-Qaida. However, speculation from police officers, terrorism experts, journalists, and Pakistani and Sri Lankan government ministers and officials pointed to a wide range of possible national and transnational backers for the attackers, including (in the most general terms) 'Indian hands' or the LTTE (Sri Lankan Tamil Tigers) (CNN-IBN, 2009; Thaindian News, 2009). In the latter instance, any critical analysis would need to explore the conflict's historical undertow and social justice issues, notably the crushing of the LTTE by the Sri Lankan army in May 2009, calls by the UN, many governments, and international NGOs for an independent inquiry into allegations of war crimes committed by Sri Lankan forces, and the general maltreatment of Tamil civilians during and after the war.

The strength of a critical social scientific approach comes more fully into its own when considering how sport has been historically associated with instances of state-directed terror in relation to civilian populations. For example, in 1920, during the Irish war of independence, on 'Bloody Sunday', 14 British agents and auxiliaries were killed in Dublin by the Irish Republican Army; later that day, British troops fired on spectators at a Gaelic football match in Croke Park, leading to 14 people being killed and scores more injured. The indiscriminate and unprovoked shooting by British forces intensified pro-Republican sentiments in Ireland. The incident was 
also commemorated in sport when the Hogan stand at Croke Park was so-named in honour of one Gaelic football player killed in the attack (Cronin, 1999).

A second instance is the 'Tlatelolco Massacre' in Mexico City, 1968, which occurred only 10 days prior to the hosting of the Olympic Games. A demonstration in Tlatelolco Square, in the capital's centre, calling for social and political change, was violently dispersed by the full might of the Mexican army. A British sports journalist, Robert Trevor, caught up in the attack, recalled later:

When the helicopters opened fire and flares were dropped to light up the square, people were absolutely terrified. As we ran down the streets we were met by Mexican soldiers in full battle order - steel helmets, rifles - and backed by armoured cars. People were being shot at from the front, by the foot soldiers, and from behind by the helicopter gunships, so they were trapped. It was terrible, there was no escape. (BBC, 2008 online)

No accurate tally of the dead and injured was provided by state officials; estimates varying between around 30 and 300. The Mexican state and influential commentators blamed the demonstrators for provoking the police and causing the bloodshed. However, directly challenging these discursive constructions of the episode, journalists in 2001 were able to access official documents which revealed that Mexican security personnel had started the shooting, deliberately provoking the massacre (Economist, 2008a; Richman and Diaz-Cortes, 2008). In the long-term, some social justice has crept into this case, as the massacre has been commemorated by the Mexican state as a national day of mourning and by public marches on the principal anniversaries; attempts by some Mexican prosecutors to prosecute people for the massacre, including the then President, have thus far foundered.

In some cases, sport stadiums have been a site for the violence of state forces against civilian populations. In Chile in the early 1970s, General Pinochet's military units and death squads detained, tortured and killed thousands of opponents in the national stadium (Hachleitner, 2005). In 1939, the Gestapo imprisoned more than 1000 Jewish men in the Prater Stadium in Vienna. After being examined by members of the anthropology department in Vienna's Natural History Museum, the men were deported to the Buchenwald concentration camp. Twenty-six men survived. One day after the deportation, a football match was staged in the stadium (Forster and Spring, 2008).

More recently, in Guinea in 2009, a pro-democracy rally in the national football stadium was attacked by security forces who fired on the crowd; more than 150 people were killed, thousands 
more were injured, and women suffered systematic mass rapes by soldiers and police (Doyle, 2009). The Guinea military junta and police sought to cover up the massacre, claiming that only a few had been killed by rogue elements in the army, while attempting to bury the dead in secret mass graves. Yet, in line with methodological glocalism, it could be argued that local, continental and transnational forces came into play in reporting and responding to the massacre. Progressive African and transnational media and NGOs helped to report the scale of the massacre and to win support in the international community for action against the military regime. The United Nations and international NGOs argued that a case for 'crimes against humanity' should be pursued against those responsible (Human Rights Watch, 2009). Several months later, the head of state survived an assassination attempt but was ousted by another military leader; and, international calls for legal action have largely foundered.

Analysis of such events should not obfuscate the very real intentions and consequences behind these terrorizing and murderous actions. However, in exploring the public meanings of terror we may extend our constructivist approach in cultural anthropological terms, to explore how, at everyday level, the meaning of the sport stadium is distorted, to become a site of terror, fear and anxiety; a labyrinthine space that provokes 'topophobia' rather than 'topophilia': that is, a fear rather than a love of place (Bale, 1994; Eichberg, 1995).

In developed nations, it is possible to identify rather more subtle interplays between the state, terrorism, discursive constructions, and social justice. We may consider, for example, how dominant forces within society extend the label 'terrorist' to encompass a broad range of perceived enemies. In the 1980s in the UK, the authoritarian New Right government under Margaret Thatcher arrayed its repressive state apparatuses against a mixture of 'internal enemies' which included paramilitary groups in Northern Ireland, unionized labour undertaking industrial action (especially the miners), football hooligans, inner-city rioters, street criminals, the young working-classes, ethnic minorities, poor single parents, the unemployed, and benefit claimants. As with these other outsider groups, the professed 'war' on football hooligans was waged at a number of levels:

legal, through punitive sentencing and new laws, such as the Football Offences Act 1991, and the Football Disorder Act 2000;

bureaucratic, through more specialized policing frameworks, such as within the National Criminal Intelligence Service, which included a 'National Football Intelligence Unit' and other units investigating serious organized crime; bio-technological, through new security technologies and architectures to discipline and control behaviour inside stadiums; the strongest illustrations 
occurred inside stadiums, through all-seated stands (which served to pacify and to facilitate the monitoring of spectators), and CCTV systems.

community policy, through the complete absence of public funding for community workers to engage with young spectators - unlike much of mainland Europe.

discursive-ideological, through the diffuse, negative labelling of hooligans and other 'enemies'.

Yet, drawing on postmodern social theory, we might identify some rather ironic symmetries between the New Right state and its hooligan 'enemies'. For the French social theorist Jean Baudrillard (1993), English football hooliganism appears as the 'mirror of terrorism', which both dares the state to act, while being a direct product of the state's callous social policies. Baudrillard examined the 1985 Heysel disaster as a form of 'hypermodern' terrorist event, wherein spectators intervene to take over from the football players as the main protagonists in the spectacle. The disaster occurred at the 1985 European Cup final, contested by Liverpool and Juventus at the Heysel Stadium in Brussels. Prior to kick-off, Liverpool fans charged at their Italian counterparts, who fled, leading to a collapsed wall due to crowd-crushing. Thirty-nine Juventus fans were fatally injured.

Meanwhile, the media are already there, waiting in advance, primed to screen the disorder for a global audience. For Baudrillard (1993: 79), hooligans are 'no different from terrorists', because they 'carry participation to its tragic limit, while at the same time daring the State to respond with violence, to liquidate them'. In the UK context, such violence was also a kind of fatalistic response to the Thatcher government's highly provocative, draconian 'state terrorism' against 'unemployed hooligans', striking miners and other citizens. The 'calculated bloody-mindedness' of Thatcher's social policies drove these marginalized groups into suicidal actions, such as publicly discredited strikes or violence inside stadiums. For the fans at Heysel, 'it is as though she [Thatcher] turns them into commandos herself, then sends them abroad; she condemns them, of course, but their brutality remains the very same brutality that she demonstrates in the exercise of her power' (Baudrillard, 1993: 78). While the analysis is characteristically provocative, Baudrillard does point towards significant elements in our critical social scientific approach, such as the discursive construction of 'terrorist' labels, the ironic interconnections between 'terrorists' and 'anti-terrorist' strategies, and issues relating to social justice. In research that would have intrigued Baudrillard, a report to Demos, the left-of-centre UK think-tank, identified a continuity between political and football 'terrorists', in that young Muslims who might have a potential propensity to violence were seen as having stronger parallels with football hooligans than with radical, peaceful Muslims (Bartlett et al., 2010). 
Overall, as these illustrations demonstrate, the adoption of a critical social scientific approach facilitates a deeper understanding of the sport/terrorism couplet. The approach requires us to probe into the sociological background and context of 'terrorist' incidents, highlighting their different 'glocal' scales of influence (local, national, continental, and transnational), their interrelations and impacts on diverse social fields (such as the economics of sport, social policy, urban planning), and the complex roles of states in defining, provoking and initiating 'terrorist' incidents. In the next section, we turn to explore the pressing issues relating to 'terror' and 'terrorism' in respect to contemporary sport mega-events.

\section{Contemporary 'terror' issues and sport mega-events}

Contemporary 'terror' issues for sport mega-events need to be located within the post-9/11 context. In this period, security budgets have mushroomed, while there has been a stronger political, public and media focus on terrorist threats and counter-terrorist strategies. Here, we explore eight main issues with regard to the contemporary sport/terror couplet.

First, cities and nations that bid for, or host, sport mega-events are now expected to project strong forms of anti-terrorist 'resilience' before international audiences (Boyle and Haggerty, 2009). A wide range of strategies are expected to feed into anti-terrorist preparations. New legislation may be enacted, providing police with greater powers for the social control and surveillance of public spaces, while restricting civil liberties such as the right to political protest or free association. New technologies may be in place, to facilitate the more intensified control and surveillance of public spaces (Lenskyj, 2002). Public and political support for these measures is pursued through the dissemination of key messages regarding the security challenges and dangers that are faced by hosting mega-events.

These different aspects of hosting or bidding for sport mega-events may be understood through critical social scientific analysis that centres on discursive constructions, strategies and structures of anti-terror, methods and scale, and social justice. For example, in order to win the bid for the 2012 Olympics, the London bidding team had to project the city's anti-terrorist resilience before the International Olympic Committee and international audiences. To gain national support for a large security budget (estimated at US $\$ 1.7$ billion), and new powers of surveillance and social control, the police and political authorities referred to hosting the event as 'the greatest security challenge that the UK has faced since the Second World War' (Gardham, 2009). In terms of hardware, an additional 900 day/night-vision surveillance cameras will be in place in London, new software is intended to integrate the capital's different CCTV systems, and the British RAF 
will fly unmanned drone aircraft, equipped with missiles and bombs, for the first time over the city (Bruce, 2008). In terms of legislation, the Olympics Act 2006 includes sections 19 and 22 which empower police to enter private property in order to confiscate unauthorized protest or advertising materials. Section 44 of the Terrorism Act 2000, enabling police freely to stop and search any vehicle or member of the public, had been expected to be widely used during the event. The social justice and civil liberties issues here have been contested, with support coming from the European legal system. The latter legislation was ruled unlawful by the European Court of Human Rights in 2010, and subsequently came under governmental review.

Second, we need to consider the labelling process in constructing terrorist 'threats' to sport events, examining in particular the role of mass media in amplifying concerns. The negative labelling of political opponents in relation to these events has been apparent in the past. Prior to Beijing 2008, Chinese police announced that they had foiled a planned terrorist attack by a separatist group of Uighur Muslims from Xianjiang province. No evidence was initially provided, while it is also notable that human rights groups had previously highlighted the poor treatment of Uighur Muslims by the Chinese police and state in general. Nevertheless, the association of the Uighur separatist movement with terrorist intentions had been made before a global audience (Kristof, 2008; Yu et al., 2009).

Third, strategies and structures of anti-terrorism have wider impacts beyond the immediate hosting of the sport mega-event. Increasingly obvious illustrations arise in regard to urban planning. Where the sport mega-events are planned to take place in inner-city or 'high-density' settings, urban clearing programmes are often implemented, whereby poor and marginalized communities are driven out, to accommodate wealthier and more 'trustworthy' home-owners and consumers. In emerging nations such as India, China and South Africa, which have hosted mega-events in recent years, urban redevelopment programmes have resulted in systematic social injustices, as hundreds of thousands of citizens are rendered homeless or forcibly relocated to neighbourhoods many miles from their home (Selva, 2005; Sudworth, 2006).

In turn, citizens of cities and nations must consider if they wish to live with the security legacies that derive from sport mega-events. Long after the event has left town, the legislation, surveillance technologies, urban redevelopment and other transformations may all remain in place, as security-focused measures that structure, frame and film everyday social life. Critical social scientists certainly have a role to play in contributing to public debates on these issues. 
Fourth, the securing and redevelopment of urban space is often closely tied to the 'festivalization' of the host city. That is, sport mega-events are a key component of wider civic strategies that present the city to investors and audiences as an attractive location for future festival events (Häussermann and Siebel, 1993; Klauser, 2011). In the Global North, these strategies are often closely tied to broader post-industrial, urban regeneration strategies.

Fifth, we witness the growing interconnections of sport mega-events and advanced militaryindustrial complexes. The provision of security technologies and systems for sport mega-events is a multi-billion dollar industry. For the Beijing Olympics, security technologies were provided by many international companies such as GE, Honeywell, Panasonic, Siemens and IBM (Bradsher, 2007). As one analyst from the US-based Security Industry Association stated, megaevents like the Olympics 'not only showcase world-class athletes, they showcase world-class security technologies and services from our industry' (Bristow, 2008). Such events enable security companies to pilot and display exemplary security technologies that may be transferred into more routine social environments.

Sixth, contemporary security strategies for sport mega-events are party to the post-modern blurring of boundaries between military and civilian spheres. We see the entry of military technologies, strategies and logics for the surveillance and control of populations in and around stadiums. The simple, conventional and, indeed, increasingly familiar model of this process features thousands of troops being mobilized, while military hardware (CCTV and many other technologies) are installed in urban centres. Militarized anti-terror drills, exercises and simulations are implemented, to test the preparatory standards of mega-events for possible terrorist attack. More subtly, major sport stadiums are inevitably absorbed by the new military urbanism, wherein urban planning and architectures are influenced by techniques of population containment and surveillance which derive from the futuristic textbooks of occupying forces (Graham, 2010; Schimmel, 2006).

Seventh, a particular set of security concerns centre on emerging nations in the Global South, where a growing number of sport mega-events are now hosted: for example, the 2016 Olympics in Rio, 2010 and 2014 World Cup finals in South Africa and Brazil respectively, and the 2010 Commonwealth Games in Delhi. Such events generate distinctive issues regarding the interplay between urban development, violent crime, and the state's monopoly on violence. In Rio de Janeiro, the city authorities have sought to impose forcibly their control over violent crime, in part to demonstrate their suitability for the hosting of the 2014 World Cup finals and the 2016 
Olympic Games. In November 2010, the Brazilian police and army mounted an invasion of the Alemao favela, to bring 'freedom' to residents and to crush criminal gangs which had controlled the area; at least 46 people were killed during the operation (Yapp, 2010).

In South Africa in 2008, prior to the World Cup finals, anti-foreigner violence swept through townships in the Johannesburg area, being aimed particularly at illegal Zimbabwean migrants who had fled the Mugabe regime. At least 24 people were killed, and many more were injured or raped (Economist, 2008b). While the violence was subsequently contained and reduced, civil society organizations in South Africa reported that local people were routinely threatening migrant groups, and that further attacks would occur after the World Cup finals were over, when the world was no longer watching (Keim, 2010).

Eighth, a final point to consider here relates to the geo-social scales of sport mega-events, no matter where they are taking place. The externalities of the sport/terror couplet extend well beyond the nation that hosts mega-events, and thus encompass 'virtual' cultures and levels of attack. For example, in Somalia, television viewers of World Cup fixtures were threatened by Islamic militias with death or flogging if they were caught watching games. In Uganda, 74 people were killed and scores injured when Islamic groups set off bombs in public locations frequented by Westerners (Rise, 2010). Thus, research into 'terror' issues at sport mega-events requires a glocal methodology, in terms of addressing the local, national, continental, and transnational dimensions.

Host nations for sport mega-events are also guarding against forms of 'cyber-terrorism' that may occur during these events. It was reported that Beijing experienced 12 million cyber attacks each day during the 2008 Olympics (Ormsby, 2010). In November 2010, the UK government announced new cyber-security plans, to safeguard IT networks and to prevent internet crime, as part of a wider package of counter-terrorism measures for the Olympics (Home Office, 2010). Yet the actual meaning of this 'cyber-terrorism' is particularly unclear and problematic. Some of these measures point vaguely towards safeguarding the UK economy, but there are few signs here of threats and violence which our definition of terrorism would require. Thus, the 'cyberterrorism' issue, at least in relation to sport mega-events, represents another area in which analysts need to examine critically the labelling processes behind the 'terrorist' category.

\section{Concluding comments}


In this discussion we have set out how a critical social theory may combine influences from sociology, human geography, and critical terrorism studies, in order to examine the interplay between sport and terrorism. The main tenets of this critical social theory, in regard to the sport/terrorism couplet, centred on the epistemologies and discursive constructions of terror, strategies and structures of anti-terror, methods and scale, and social and spatial justice. Such a critical social theory enables us to clarify and resolve the epistemological and methodological problems that arise over recent developments in the sport/terrorism couplet. In our view, the main aspects of this theory may also be transferred to examine many other fields of inquiry for social scientists.

The critical social scientific approach draws attention to several prominent issues with regard to the sport/terrorism couplet. We have argued that critical analysis needs to focus closely on the complex and murky backgrounds surrounding 'terrorist' incidents; the role of states in defining, provoking and initiating 'terrorist' incidents; and, the ways in which a 'counter-terrorist' approach engages or dovetails with a wide range of repressive or ideological instruments, in regard to legislation, policing, and social policies towards marginalized groups. The overall approach which we have favoured here leans more towards the traditions of established critical theory than towards post-structuralist theory, in order to enable discussion of social justice issues, and to retain the potential meaningfulness of the term 'terror' per se. In our view, the critical social scientific approach is particularly helpful for exploring contemporary sport terrorism budgets, technical measures and policy strategies that spread widely across the social field; uncritical media reports regarding 'terrorist' threats; the introduction of state-of-the-art security technologies and military-influenced planning within cities; and, the 'glocal' diffusion of the 'terror' issue, across local, national, continental and transnational domains.

One of the important corollaries of this critical approach concerns the public role of social science. In this instance, critical social scientists need to engage with social justice issues - for example, in protecting the interests of marginalized or disempowered citizens - and in so doing, to contribute fully to public debates on the full range of social impacts and legacies of sport mega-events.

Two final, inter-related points to consider here relate to the future social position of elite level sport, as the latter becomes central to international society. First, many sport governing bodies and mega-events are coated in universalist discourses regarding humanity. Such messages jar increasingly with a growing stream of reports from critical investigative journalists, non- 
governmental organizations, and social scientists, on the corruption and cronyism in leading sports institutions, and the infringements of civil or human rights in nations that are hosting major sporting events (see, for example, BBC, 2010; Eick, 2011; Jennings, 2006; Lenskyj, 2002). This critical spotlight will certainly shine more glaringly in future years on sport mega-events, their host nations, and governing bodies. Future lines of analysis are likely to continue the focus on how anti-terrorist strategies impact upon the civil liberties of citizens, and on the more general waging of 'wars on terror' against specific populations. One way forward for sport governing bodies would be to allocate sport mega-events to host nations with greater reference to these issues.

Second, we need to locate the sport/terrorism couplet within the wider context of how sport institutions have sought to carve out a role for themselves within wider international society. In recent years we have witnessed the rise of the 'Sport for Development and Peace' (SDP) sector, in which sport institutions have formed partnerships with diverse private, public and voluntary organizations, to use sport as a tool for promoting social development and peaceful relations within zones of social conflict and underdevelopment (Giulianotti, 2011a, 2011b). In support of this role, sport institutions have been relatively successful in presenting themselves as more politically neutral or value-free than many other cultural movements and forces that are centred in the Global North. Sport governing bodies have a complex balancing act to play here if they are to maintain both their aggressive international growth strategies and their claims to forms of political neutrality. As they engage increasingly with pro-development and/or pro-commercial institutions, sport bodies, and the events which they control, may become more commonly associated with particular 'sides' in violent conflicts. In such circumstances, the sport/terrorism couplet would be reconfigured and would acquire far greater significance, as sport institutions and events would find themselves more open to being defined as 'legitimate' targets for violent attacks by participants in armed conflicts and struggles.

\section{References}

Adorno T and Horkheimer M (1979) Dialectic of Enlightenment. London: Verso.

Bale J (1994) Landscapes of Modern Sport. London: Leicester University Press.

Bartlett J, Birdwell J and King M (2010) The Edge of Violence. London: Demos.

Baudrillard J (1993) The Transparency of Evil. London: Verso.

BBC (2008) The most terrifying night of my life, 2 October. Available at: http://news.bbc.co.uk/2/hi/americas/7646473.stm (accessed 20 January 2011). 
BBC (2010) FIFA launches investigation into vote selling claims, 17 October. Available at: http://news.bbc.co.uk/sport1/hi/football/9099326.stm (accessed 25 January 2011).

Beck U (2006) Living in the world risk society. Economy and Society 35(3): 329-345.

Beck U (2007) The cosmopolitan condition: Why methodological nationalism fails. Theory, Culture \& Society 24(7-8): 286-290.

Boyle P and Haggerty KD (2009) Spectacular security: Mega-events and the security complex. Political Sociology 3: 257-274.

Bradsher K (2007) China finds American allies for security. New York Times, 28 December, available at: http://www.nytimes.com/2007/12/28/business/worldbusiness/28security.html (accessed 20 January 2011).

Bristow M (2008) China's Olympic security dilemma. BBC News, 12 March, available at: http:/ / news.bbc.co.uk/2/hi/asia-pacific/7292025.stm (accessed 20 January 2011).

Bruce I (2008) RAF drones to be used for 2012 Olympics security. The Harald, 9 January, available at: http://www.heraldscotland.com/raf-drones-to-be-used-for-2012-olympicssecurity-1.872224 (accessed 20 January 2011).

Calhoun C (1993) Habitus, field, and capital: The question of historical specificity. In: Calhoun C, LiPuma E and Postone M (eds) Bourdieu: Critical Perspectives. Chicago, IL: University of Chicago Press, 61-88.

Calhoun C (1995) Critical Social Theory: Culture, History and the Challenge of Difference. Oxford: Blackwell.

CNN-IBN (2009) Lankan group bebind SL cricket team attack: Pak, 6 September, available at: http://ibnlive.in.com/news/lankan-group-behind-sl-cricket-team-attack-pak/100794-2.html (accessed 20 January 2011).

Cronin M (1999) Sport and Nationalism in Ireland: Gaelic Games, Soccer and Irish Identity since 1884. Dublin: Four Courts Press.

Desbiens C and Smith N (1999) The International Critical Geography Group: Forbidden optimism? Environment and Planning D: Society and Space 17: 379-382.

Doyle M (2009) Unearthing the truth of Guinea 'bloodbath'. BBC News, 25 November, available at: http://news.bbc.co.uk/1/hi/8376800.stm (accessed 20 January 2011).

Economist (2008a) The ghosts of Mexico 1968. A massacre that was hushed up to ensure a 'successful' sporting event, 24 April. Available at: http://www.economist.com/node/11090825 (accessed 20 January 2011).

Economist (2008b) Nowhere left to go. Xenophobic violence rocks South Africa's biggest city, 20 May. Available at: http://www.economist.com/node/11399350 (accessed 20 January 2011).

Eichberg H (1995) Stadium, pyramid, labyrinth. In: Bale J and Moen O (eds) The Stadium and the City. Keele: Keele University Press, 323-347.

Eick V (2011) Lack of legacy? Shadows of surveillance after the German 2006 FIFA World Cup. Urban Studies 48: 3329-3345.

Forster D and Spring C (2008) Haftort: Praterstadion, Sektor B. In: Eppel P, Hachleitner B, Schwarz W and Spitaler G (eds) Wo die Wuchtel fliegt. Legendäre Orte des Wiener Fußballs. Wien: Löcker, 51.

Foucault M (2009) Security, Territory, Population. Lectures at the Collège de France 1977-1978. New York: Palgrave Macmillan. 
Gardham D (2009) Olympics 'biggest security challenge since WW2'. Daily Telegraph, 13 November, available

http://www.telegraph.co.uk/sport/othersports/olympics/6562050/Olympics-biggestsecurity-challenge-since-WW2.html (accessed 20 January 2011).

Giulianotti R (2011a) Sport, peacemaking and conflict resolution: A contextual analysis and modelling of the sport, development and peace sector. Ethnic and Racial Studies 34(2): 207-228.

Giulianotti R (2011b) The sport, development and peace sector: A model of four social policy domains. Journal of Social Policy 40: 757-776.

Graham S (2010) Cities under Siege. The New Military Urbanism. London: Verso.

Hachleitner B (2005) Das Stadium als Gefängnis. In: Marschik M, Müllner R, Spitaler G and Zinganel M (eds) Das Stadion. Geschichte, Architektur, Politik, Ökonomie. Vienna: Turia \& Kant, 258-281.

Harvey D (1973) Social Justice and the City. London: Edward Arnold.

Häussermann H and Siebel W (1993) Festivalisierung der Stadtpolitik. Stadtentwicklung durch große Projekte. Opladen: Westdeutscher Verlag.

Holton R (2008) Global Networks. Basingstoke: Palgrave Macmillan.

Home Office (2010) Olympic cyber security plan to be developed, 25 November. Available at: http://www.homeoffice.gov.uk/media-centre/news/olympic-cyber (accessed 20 January 2011).

Human Rights Watch (2009) Bloody Monday: The September 28 Massacre and Rapes by Security Forces in Guinea. New York: Human Rights Watch.

Jackson R (2007) The core commitments of critical terrorism studies. European Political Science 6(3): $244-251$.

Jackson R, Smyth MB and Gunning J (eds) (2009) Critical Terrorism Studies: A New Research Agenda. London: Routledge.

Jennings A (2006) Foul! The Secret World of FIFA: Bribes, Vote Rigging and Ticket Scandals. London: Harper Sport.

Katz C (1998) Lost and found in the posts: Addressing critical human geography. Environment and Planning D: Society and Space 16: 257-278.

Keim M (2010) Football as social development in South Africa. Keynote paper to the international conference, Centers and Peripheries in Sport, Malmö University, Sweden, 8-12 April.

Keohane RO (2002) The globalization of informal violence, theories of world politics, and 'the liberalism of fear'. In: Calhoun C, Price P and Timmer A (eds) Understanding September 11. New York: New Press, 76-91.

Klauser F (2011) Interpretative flexibility of the event-city: Security, branding and urban entrepreneurialism at the European Football Championships 2008. International Journal of Urban and Regional Research (available in the early view online section: http:/ / onlinelibrary.wiley.com/doi/10.1111/j.1468-2427.2011.01064.x/pdf).

Kristof ND (2008) Terrorism and the Olympics. New York Times, 29 May, available at: http://www.nytimes.com/2008/05/29/opinion/29kristof.html?_r=1\&\#x00026adxnnl=1\&a dxnnlx=1295535659-46WktEwSa1VuXJ5A/oD5Sw (accessed 20 January 2011). 
Lees L (1999) Critical geography and the opening up of the academy: Lessons from 'real life' attempts. Area 31(4): 377-383.

Lenskyj HJ (2002) The Best Olympics Ever? Social Impacts of Sydney 2000. New York: State University of New York Press.

Manthorp N (2009) South Africa pulls out stops to host IPL. The Guardian, 23 March, available at: http://www.guardian.co.uk/sport/2009/mar/23/south-africa-indian-premier-league-iplbid (accessed 20 January 2011).

Marcuse H (1986) One-Dimensional Man. London: Ark.

McDonald M (2009) Emancipation and critical terrorism studies. In: Jackson R, Smyth MB and Gunning J (eds) Critical Terrorism Studies: A New Research Agenda. London: Routledge, 109-123.

Ormsby A (2010) London Olympics 'unavoidably attractive' for cyber attacks. Reuters, 25 November, available at: http://uk.reuters.com/article/idUKTRE6AO2QY20101125 (accessed 20 January 2011).

Raphael S (2009) In the service of power: Terrorism studies and US Intervention in the Global South. In: Jackson R, Smyth MB and Gunning J (eds) Critical Terrorism Studies: A New Research Agenda. London: Routledge, 49-65.

Richman J and Diaz-Cortes A (2008) Mexico's 1968 massacre: What really happened? Radio Diaries, 1 December, available at: http://www.npr.org/templates/story/story.php?storyId=97546687 (accessed 20 January 2011).

Rise X (2010) Uganda bomb blasts kill at least 74. The Guardian, 12 July, available at: http://www.guardian.co.uk/world/2010/jul/12/uganda-kampala-bombs-explosions-attacks (accessed 20 January 2011).

Robertson R (1992) Globalization: Social Theory and Global Culture. London: SAGE.

Said E (1988) Identity, negation and violence. New Left Review 171: 46-60.

Schiller K and Young C (2010) The 1972 Olympics and the Making of Modern Germany. Los Angeles: University of California Press.

Schimmel K (2006) Deep play: Major sports and urban social conditions in the USA. Sociological Review 54(2): 160-174.

Selva M (2005) South Africa uses apartheid laws to evict thousands for World Cup. The Independent, 30 July, available at: http://www.independent.co.uk/news/world/africa/southafrica-uses-apartheid-laws-to-evict-thousands-for-world-cup-500694.html (accessed 20 January 2011).

Shah S and Pallister D (2009) Pakistan police claim arrests over gun attack on Sri Lankan cricket team. The Guardian, 4 March, available at: http://www.guardian.co.uk/world/2009/mar/04/pakistan-srilanka (accessed 20 January 2011).

Sluka JA (2009) The contribution of anthropology to critical terrorism studies. In: Jackson R, Smyth MB and Gunning J (eds) Critical Terrorism Studies: A New Research Agenda. London: Routledge, 138-155.

Sudworth J (2006) Slum dispute over Commonwealth Games. BBC News, 21 October, available at: http://news.bbc.co.uk/1/hi/world/south_asia/5325034.stm (accessed 20 January 2011). 
Thaindian News (2009) Indian hand in Sri Lankan cricket team attack: Pakistan, 10 April. Available at: http://www.thaindian.com/newsportal/india-news/indian-hand-in-sri-lankan-cricketteam-attack-pakistan_100178135.html (accessed 20 January 2011).

Tilly C (2004) Terror, terrorism, terrorists. Sociological Theory 22(1): 5-13.

Toros H and Gunning J (2009) Exploring a critical theory approach to terrorism studies. In: Jackson R, Smyth MB and Gunning J (eds) Critical Terrorism Studies: A New Research Agenda. London: Routledge, 87-108.

Willis E (1996) The Sociological Quest. New Brunswick, NJ: Rutgers University Press.

Wilson R (2009) Cricket move boost for South Africa. BBC News, 17 April, available at: http:// news.bbc.co.uk/1/hi/8001792.stm (accessed 20 January 2011).

Yapp R (2010) Brazil police claim victory in drugs 'war'. Daily Telegraph, 28 November, available at: http://www.telegraph.co.uk/news/worldnews/southamerica/brazil/8166143/Brazilpolice-claim-victory-in-drugs-war.html (accessed 20 January 2011).

Yu Y, Klauser F and Chan G (2009) Governing security at the 2008 Beijing Olympics. International Journal of the History of Sport 26(3): 390-405.

Zulaika J (2009) Terrorism: The Self-Fulfilling Prophecy. Chicago, IL: University of Chicago Press.

Zulaika J and Douglass W (1996) Terror and Taboo: The Follies, Fables, and Faces of Terrorism. London: Routledge. 